\title{
Borneo Journal of
}

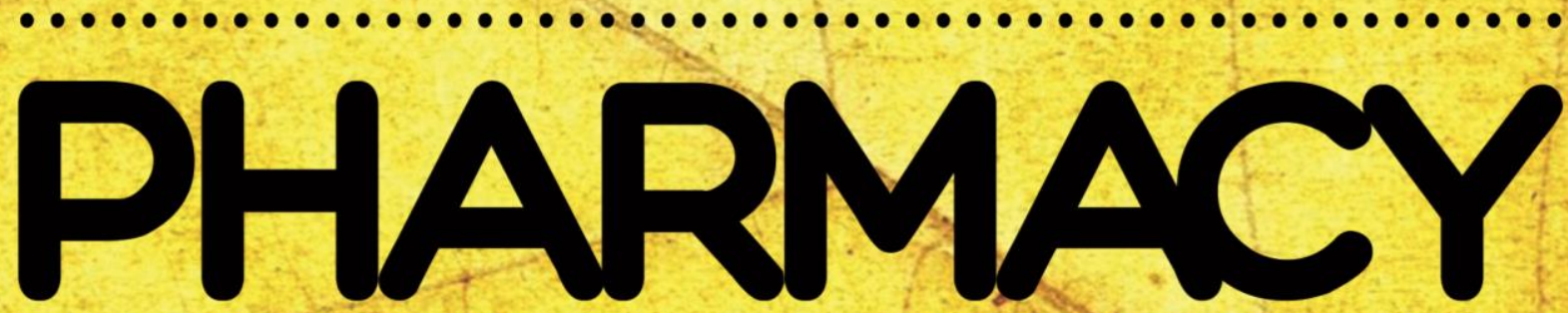

Volume 4 Issue 1 February 2021

Accredited at SINTA 2 until February 2025

by Ministry of Research and Technology / National Research and Innovation Agency, Indonesia No: 148/M/KPT/2020.

Institute for Research and Community Services Universitas Muhammadiyah Palangkaraya 


\section{BORNEO JOURNAL OF PHARMACY}

Borneo J Pharm e-ISSN: 2621-4814

Volume 4 Issue 1 February 2021

Department of Pharmacy

Faculty of Health Sciences Universitas Muhammadiyah Palangkaraya

\section{EDITOR IN CHIEF}

Mohammad Rizki Fadhil Pratama

Universitas Muhammadiyah Palangkaraya, Indonesia

ORCID: http:// orcid.org/0000-0002-0727-4392

ASSOCIATE EDITOR

Ahmed Mahal

Chinese Academy of Sciences, China

Lina Perekhoda

National University of Pharmacy, Ukraine

$$
\text { Jyoti Singh }
$$

CSIR-CIMAP, India

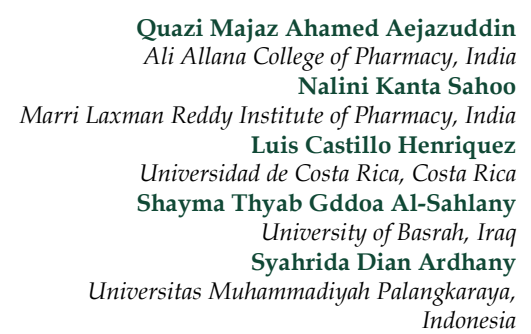

Quazi Majaz Ahamed Aejazuddin ge of Pharmacy, India Institute of Pharmacy, India Universidad de Costa Rica, Costa Rica University of Basrah, Iraq University of Basrah, Iraq
Syahrida Dian Ardhany Indonesia
Khalid Karrouchi Mohammed V University in Rabat, Morocco Alaa Kareem Niamah University of Basrah, Iraq Neni Frimayanti Sekolah Tingoi Ilmu Farmasi Riau, Indonesia Erwin Martinez Faller San Pedro College, Philippines Susi Novaryatiin Universitas Muhammadiyah Palangkaraya, Indonesia

\section{REVIEWER}

Keni Vidilaseris

University of Helsinki, Finland

Oleh M Koshovyi

National University of Pharmacy, Ukraine

Atul Kabra

Raffles University, India

Arthi Venkatesan

ALTEM Technologies, India

Ashraf Ahmed Ali Abdusalam

Sirte University, Libya

Adryan Fristiohady

Universitas Halu Oleo, Indonesia

Prayasee Baruah

North-Eastern Hill University, India

Santwana Palai

Odisha University of Agriculture and

Technology, India

Saeful Amin

Sekolah Tinggi Ilmu Kesehatan Bakti Tunas

Husada, Indonesia

Hasyrul Hamzah

Universitas Muhammadiyah Kalimantan

Timur, Indonesia
Nurolaini Kifli

Universiti Brunei Darussalam, Brunei Darussalam

Alexandru Mihai Grumezescu

Politechnica University of Bucharest, Romania

Anna Vladimirovna Kurkina

Samara State Medical University, Russia

A Lalithamma

Karpaga Vinayaga Institute of Medical Sciences, India Julaeha

Universitas 17 Agustus 1945 Jakarta, Indonesia Ihsanul Arief

Akademi Farmasi Yarsi Pontianak, Indonesia

Mohammed Gamal

Jouf University, Saudi Arabia

Dian Wuri Astuti

Sekolah Tinggi Ilmu Kesehatan Guna Bangsa

Yogyakarta, Indonesia

Monaj Kumar Sarkar

Shanmugha Arts, Science, Technology and Research

Academy (SASTRA) Deemed University, India

Hafsan

Universitas Islam Negeri Alauddin Makassar,

Indonesia

\section{Mahendran Sekar}

Universiti Kuala Lumpur, Malaysia

Punet Kumar

Shri Gopichand College of Pharmacy, India Rimadani Pratiwi

Universitas Padjadjaran, Indonesia Ruqiah Ganda Putri Panjaitan

Universitas Tanjungpura, Indonesia

Sutomo

Universitas Lambung Mangkurat, Indonesia Arnida

Universitas Lambung Mangkurat, Indonesia

Andhika Bintang Mahardhika

Institut Teknologi Bandung, Indonesia

Isna Rasdianah Aziz

Universitas Islam Negeri Alauddin

Makassar, Indonesia

Dhafer Saber Zinad

University of Technology, Iraq

COVER E LAYOUT DESIGN

\section{PUBLISHED BY}

Syahrida Dian Ardhany

Institute for Research and Community Services

Universitas Muhammadiyah Palangkaraya

RTA Milono St. Km. 1,5 Palangka Raya 73111

1p2m@umpalangkaraya.ac.idbjop

http://journal.umpalangkaraya.ac.id/index.php/bjop 
EDITORIAL WORDS

apt. Mohammad Rizki Fadhil Pratama, S.Farm., M.Si.

Editor in Chief

Borneo J Pharm

Assalamu'alaikum Wr. Wb.

Alhamdulillahirabbil 'alamin. The next edition of Borneo Journal of Pharmacy (Borneo J Pharm), has been published at February 2021. Starting from this edition, Borneo J Pharm increases the frequency of publishing four times a year. This change aims to improve circulation of the best articles published by Borneo J Pharm. Also, starting from this edition, Borneo J Pharm applying the publish-as-you-go issue to present the title of the article that has been received as early as possible in order to increase the chances of readability and quotation of articles in Borneo J Pharm.

Starting in the 2019 edition, Borneo J Pharm has been accepted for indexing in EMBASE by Elsevier dan CAS. This is an acknowledgment of the quality of the publications presented by Borneo J Pharm. In addition, Borneo J Pharm has also been accredited at SINTA in rank 2. In the future, Borneo J Pharm will try to improve the indexing to ESCI by Web of Sciences and SCOPUS. We will ensure this achievement as a start and will continue to improve the quality of Borneo J Pharm.

This edition contains ten articles consisting of Pharmacognosy-Phytochemistry, Pharmaceutical, Analytical Pharmacy-Medicinal Chemistry, Natural Product Development, and Clinical-Community Pharmacy. This edition includes writings from four countries including Indonesia, India, Malaysia, and Nigeria. The authors come from several institutions, including Universitas Muhammadiyah Palangkaraya, Universitas Muhammadiyah Surakarta, Universitas Muhammadiyah Malang, Universiti Teknologi MARA Cawangan Sarawak, Politeknik Bina Husada Kendari, Universitas Halu Oleo, Akademi Farmasi Surabaya, Universitas Hang Tuah, Universitas Mandala Waluya, Universitas Gadjah Mada, Universitas Abdurrab, Federal University of Technology Minna, Humera Khan College of Pharmacy, University of Abuja, and Universitas Ahmad Dahlan.

Editorial boards are fully aware that there are still room for improvement in this edition, hence with all humility willing to accept constructive suggestions and feedback for improvements to the publication for the next editions. The editorial board would like to thank all editors and reviewers, and contributors of the scientific articles who have provided the repetoire in this issue. We hope that all parties, especially the contributors of the articles, could re-participate for the the publication in the next edition on May 2021.

Wassalamu'alaikum Wr. Wb.

Palangka Raya, February 2021

Editor-in-Chief 
Phytochemical and Cytotoxic Test of Durio kutejensis Root Bark on MCF-7 Cells

Muhammad Priyadi / Universitas Muhammadiyah Palangkaraya

Haryoto / Universitas Muhammadiyah Surakarta

Amaliyah Dina Anggraeni / Universitas Muhammadiyah Malang

Heng Yen Khong / Universiti Teknologi MARA Cawangan Sarawak

$1-5$

Total Phenolic and Flavonoid Content, Antioxidant, and Toxicity Test with BSLT of Meistera chinensis Fruit Fraction from Southeast Sulawesi

Musdalipah / Politeknik Bina Husada Kendari

Selfyana Austin Tee / Politeknik Bina Husada Kendari

Karmilah / Politeknik Bina Husada Kendari

Sahidin / Universitas Halu Oleo

Adryan Fristiohady / Universitas Halu Oleo

Agung Wibawa Mahatva Yodha / Universitas Halu Oleo

$6-15$

Sections: PHARMACEUTICAL

Formulation and Evaluation of Solid Dispersion Chitosan Tablet from Whiteleg Shrimp (Litopenaeus vannamei) Using PVP K-30 As a Carriers Hilya Nur Imtihani / Akademi Farmasi Surabaya Fitria Abbas Thalib / Akademi Farmasi Surabaya Silfiana Nisa Permatasari / Akademi Farmasi Surabaya $16-21$

Antioxidant and UV Protection Activities of Squid (Loligo sp.) Ink Powder Lotions Dyah Rahmasari / Universitas Muhammadiyah Malang Aulia Juwanti / Universitas Muhammadiyah Malang

Ima Pratiwi / Universitas Muhammadiyah Malang Novia Zulfa Diana / Universitas Muhammadiyah Malang Raditya Weka Nugraheni / Universitas Muhammadiyah Malang Dita Nurlita Rakhma / Universitas Hang Tuah $22-28$

\section{Sections: ANALYTICAL PHARMACY-MEDICINAL CHEMISTRY}

GC-MS Analysis of Bioactive Compounds in Ethanol and Ethyl Acetate Fraction of Grapefruit (Citrus maxima L.) Rind

La Ode Muhammad Andi Zulbayu / Universitas Mandala Waluya; Universitas Gadjah Mada

Endang Lukitaningsih / Universitas Gadjah Mada

Rumiyati / Universitas Gadjah Mada

$29-35$ 
The Combination of Turmeric (Curcuma domestica) Rhizome Extract and Collagen in A Serum Formulation as an Antioxidant

Denia Pratiwi / Universitas Abdurrab Wahyu Margi Sidoretno / Universitas Abdurrab Nur Aisah / Universitas Abdurrab $36-42$

Formulation and Antibacterial Activity of Liquid Soap Containing Ketapang (Terminalia catappa

L.) Leaves Extract

Asiska Permata Dewi / Universitas Abdurrab

Dini Mardhiyani / Universitas Abdurrab

$43-50$

Formulation, Organoleptic Evaluation, and Acceptability of Various Teas from Underutilized Nutritious Herbs Compared with Marketed Chinese and Yellow Lipton Tea Elijah Edache Ehoche / Federal University of Technology Minna

Parth Patel / Humera Khan College of Pharmacy

Chijioke Madu / University of Abuja Johnson Adejoh / University of Abuja $51-56$

Sections: CLINICAL-COMMUNITY PHARMACY

Validation of Finnish Diabetes Risk Score Indonesia Version in Yogyakarta

Putri Pertiwi / Universitas Ahmad Dahlan

Dyah Aryani Perwitasari / Universitas Ahmad Dahlan

Satibi / Universitas Gadjah Mada

$57-67$

Relationship Between Finnish Diabetic Risk Score (FINDRISC) with Health-Related Quality of Life in Yogyakarta

Ninda Sari Wahyuningtyas / Universitas Ahmad Dahlan

Dyah Aryani Perwitasari / Universitas Ahmad Dahlan

Satibi / Universitas Gadjah Mada

$68-77$ 


\title{
Author Guidelines BORNEO JOURNAL OF PHARMACY
}

\author{
Borneo J Pharm - e-ISSN: 2621-4814
}

1. Writing is the result of research or review of critical analysis study in the field but not limited to PharmacologyToxicology, Pharmacognosy-Phytochemistry, Pharmaceutical, Analytical Pharmacy-Medicinal Chemistry, Natural Product Development, Clinical-Community Pharmacy, Management Pharmacy, and other Pharmacy aspects which have never been published in other scientific publication media. Borneo Journal of Pharmacy prioritizes research articles conducted on the island of Borneo, as well as those conducted by researchers from institutions on the island of Borneo. However, articles from researchers outside the island of Borneo are also welcome.

2. Manuscripts that have been published in the form of a preprint on several platforms such as arXiv, Preprints, SSRN, and ResearchGate are welcome to publish.

3. The manuscript is written in English (Can be English American or British as long as it is consistent and does not mix the two) with Book Antiqua font 10 pt, two-column, density 1.15 spaces, on A4 paper with a top-down margin of 2.5 $\mathrm{cm}$ and right-left margins $1.5 \mathrm{~cm}$.

4. The manuscript is typed with MS-Word program using the provided template and saved in .doc or .docx format.

5. The manuscript is typed strictly with the following rules:

a. The title, short and clear, written in English. The title length does not exceed 20 words.

b. Authors, listed without mention of title or degree, under the name including the affiliation and complete address, and email of the corresponding author. The author's name, which consists of one word, must be repeated twice for first and last names. To author with names of more than two words, the author's last name consists of only one word, the rest is written as the first name.

c. Abstract, written in English which is a summary of the article. The abstract is created in one paragraph and a maximum of 250 words with Book Antiqua font 9 pt, single column, and space 1 . Points that must be listed in the abstract include the research objectives, methods, results, conclusions, and keywords. The number of keywords is between three and five keywords.

d. Introduction, contain background, reasons for the importance of underlying research or hypotheses, general approaches and objectives of the research and relevant literature review. The number of paragraphs not restricted but the contents must include background, objectives, positions on previous research, as well as the novelty of the research. The little theoretical basis which indirectly related to the contents of the article could be included without sub-chapters required. Citations are numbered consecutively in the order of appearance in the text at the end of the sentence in superscript without brackets, for example, Text ${ }^{1}$, Text ${ }^{2,3}$, and Text ${ }^{4-6}$.

e. Methodology, Research method consists of 2 sub-chapters including materials and methods. If data analysis is specific, or the way of analysis is novel, then data analysis subchapter could be added. The sub-chapters are written without numbering or bullet.

f. Results and Discussion, at least contain three subjects (1) description of results, (2) interpretation or explanation of results, and (3) comparative of results with previous studies results. If the subchapters very length could be made sub-sub-chapters with Arabic numbering. Description of the results can be in the form of tables and figures with a serial number (Table uses a sequence of Roman numerals and placed at the top, while figures using Arabic numeric sequence and placed in the below).

g. Conclusion, made in a single paragraph without the citation contains the final conclusion and suggestions for advanced research.

h. References, a list of recently selected topics is published last five years (minimum $75 \%$ of at least 15 references). The bibliography is written in chronological order with the serial number (Vancouver System) and suggested using a reference management application such as EndNote, Mendeley, Zotero, and other applications.

6. Authors whose manuscripts are published are free of charge for both Publication cost and article processing charge.

7. Authors will get full access to the article published on e-journal of Universitas Muhammadiyah Palangkaraya at the website http://journal.umpalangkaraya.ac.id/index.php/bjop. 


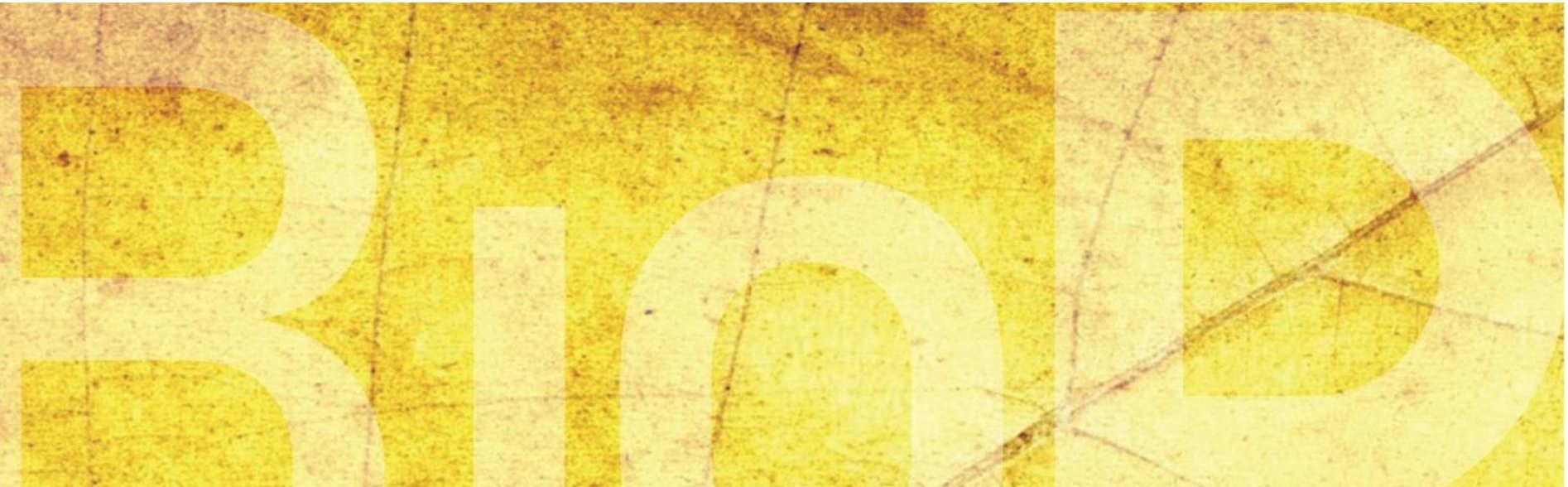

\section{Borneo Journal of \\ PHARMACY \\ Volume 4 Issue 1 February 2021}

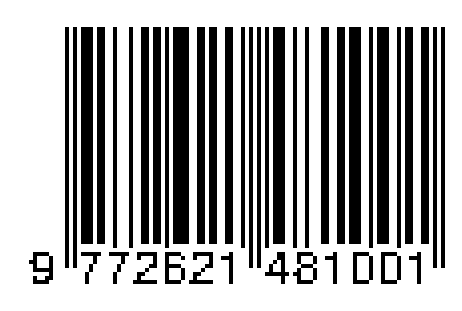

